DOI: 10.20472/IAC.2017.029.006

\author{
KHATUNA BARBAKADZE \\ Ivane Javakhishvili Tbilisi State University, Georgia
}

\title{
IMPROVEMENT ISSUES OF CORPORATE MANAGEMENT OF INVESTMENT PROCESS
}

\begin{abstract}
:
Actuality of topic. Corporate management covers a wide range of relations and its importance should be assessed accordingly. For improvement of corporate management it is necessary to raise knowledge of management structures and quality of financial reporting, as well as reliability and transparency. Successful achievement of results on all stages of investment process is possible only with properly constructed corporate management system, which includes rational distribution of rights and obligations among participants. Key elements of such system include transparency of company ownership and structure, participation of shareholders in governance and effective protection of shareholder's rights.

Object of the research - Corporate management of investment process.

The purpose of the research - Study of existing problems in corporate management of investment process and ways to improve them.

Research methods. Taking in consideration difficulties and actuality of research problem, methods of systemic, historic and logic research were used while preparing the paper. Also methods of scientific abstraction, analysis and synthesis.

Conclusion. Conclusions received from the research will eliminate existing problems in corporate management of investment process and will support growth of effectiveness.
\end{abstract}

\section{Keywords:}

Investment process; investment resoursec; financial resources; outsourcing; corporate management. 
Introduction. Corporate management covers a wide range of relations and its importance should be assessed accordingly. For improvement of corporate management it is necessary to raise knowledge of management structures and quality of financial reporting, as well as reliability and transparency. Favorable entrepreneurial and investment environment significantly affects the productivity and has direct influence on effective distribution of resources in private sector. According to global competitiveness and dynamic economic processes, constant care about improvement of entrepreneurial and investment environment is necessary, which should be reflected in establishment of new business, development of small and medium business, growth of foreign investment, in improvement of positions in international ratings and assessments.

Decesions regarding corporate management of investment process is related to the goals of companies, which except profitability includes growth of company, achievement of high labor productivity, creation of new types of products, etc. Importance of corporate management of investment process and discussion of issues of its importance became most important during last decade. Fundamentally has been changed structure of investment contributions, particularly, investment in human capital and non-material assets has been increased.

Theoretical Part. Process of creation and formation of new companies is related with principal changes of investment policy. In terms of financial, trade and informational flows of globalization, intensive growth of electronic trade has increased competiotion on market of intermediate products, Opportunities for selection of suppliers and customers has been expanded, as well as investment behavior of companies has been changed. Temporary distribution of profit plays important role in companies investment activities. According to financial conditions, management of company sets different norms of profit to investments, which gives them opportunity to manage investment resources in time.

Profit category is the basis for the traditional methods of investment decision analysis profit norm on investment and return per share. - In corporate accounts focus is made on income per share, as indicator of effectiveness of investment activity. Moreover, if company provides increase of income per share, then market value of its shares will increase neccesarily. Method of profit norm, as usually, is used for assessment of short-term projects and also for measurement of effectiveness of separate division's investments. In short period of time, capital oriented on maximum profit determines wish of investor to establish long-term relations and to participate in process of decision making and governance of company.

Implementation of particular investment project depends on existance of qualified personnel, management practice, existing technologies, type of investment and factors related to project assessment. New approaches of analysis of company activities, in particular, methotds of company value assessment for shareholders connects with each other present value of cash received from investment operations, present value of quoted securities on market and residual value of company, through 
which it is possible to determine not only project effectiveness, but its influence on company's investment positions.

In order to increase investment resources and alternative sources of financing, development of country's security market is necessary. Through the market of financial securities, free resources are efficiently channeled to productive venture, which gives stimule to growth of savings and investments. For proper functioning of securities market, encouragement of corporate governance in private sector is necessary, while proper corporate governance is prerequisite for security market development. At the same it is very important how decisions are made, how rights and responsibilities are divided, because above mentioned determines wish of investor to buy shares of company through security market.

In Georgia, market of securities is developed weakly, because of this, raising of additional investment resources for companies is related to difficulities. Growth of investment activity in corporate sector is only available through framework of own financial resources. Attraction of additional resources is necessary for governance of investment processes, which gives ability to each investor to carry out larger investments in their own business and accordingly, receive a profit.

For improvement of corporate governance it is necessary to raise knowledge of governing bodies and quality, reliability and transparency of financial reporting. Lack of transparency in operations and uncertainty of external investors (especially foreigners) in those market segment which provide growth of company's total value, hinders attraction of external capital. In order to increase financial transparency, it is necessary to expand activities of international rating companies in Georgia, which will also contribute to formation of local rating companies. Usage of rating estimations issued by reliable rating companies will support investment, regulatory and analytical activities of state, as well as private sector. In parallel with existing situation analysis in Georgia, it should be studied experience of countries like Georgia to solve the problem; it should be selected the way which is most in line with our problem and considers specifications which is typical to the given issue.

In framework of world economic development, diversification is the most important element for growth of competitiveness among companies, which on accout of creation of internal market of capital gives priority to economies of scale and to overcoming information asymmetry problems for investors, which gives possibity to managers of companies to distribute investment and financial resources from low income units to high income units. Opposite process of diversification may also occur, which is related with dismission of non profile production, sale of assets and concentration on main perspective activities. The most advanced stage on this direction is outsourcing, when company remains only functions like know-how and new production output and other marketing, main production, sales, customer service is transferred to other companies. 
In modern business, more and more companies benefit from outsourcing. In terms of globalization, tendency to benefit from outsourcing gives them ability to develop their competitiveness strategy on developing markets. If the company does not owe competitive assets, connection with outsourcing process will be possible through socalled strategy adabtation, by buying assets of multinational corporations or by entering into alliance with them. Those companies, which have competitive assets implement outsourcing by themselves and focus on the most competitive types of production.

Herewith, outsourcing is sometimes accompanied by threats. If the company can not produce such high quality products as its competitors and does not apply to outsourcing with the purpose to produce high quality products, then its derivative products and accordingly, consumer production will be low. This will reduce competitiveness as well as income, market share and other indicators of effectiveness. But if it will order other company to produce above mentioned production, then its own competitiveness will increase. Optimal decisions regarding at what level should the company rely on partners depends on concrete circumstances, on comparison of company's and potential partner's abilities. To find out whether independent production is better or outsourcing, analysis of company's strength and weaknesses is necessary. Thus, dismission of companies from non profile production and concentration process on major types of activities is very important.

There are factors influencing outsourcing positivily as well as negatively. For example, implementation of outsourcing primarily is conditioned by economy of expenses, external experience and receiving technologies, improvement of operations and services, wish to focus on main competences. In case of rejection, company should make it on account of expense growth and disqualification of own personnel. Fairly determined taxes and tax burden of population is one of the most important criteria for living standards evaluation. (Kbiladze, Kbiladze, 2016 p.191)

Research methods. Taking in consideration difficulties and actuality of research problem, methods of systemic, historic and logic research were used while preparing the paper. Also methods of scientific abstraction, analysis and synthesis.

Conclusion. Important factor of competitiveness is combination of investment process of corporate management with appropriate model of company's activity. Successful achievement of results on all stages of investment process is possible only with properly constructed corporate management system, which includes rational distribution of rights and obligations among participants. Nowadays, everyone agree that taxes play crucial role in business development of the country. (Kbiladze, Kbiladze, 2016, p.192). Key elements of such system include transparency of company ownership and structure, participation of shareholders in governance and effective protection of shareholder's rights.

Review of the literature. Corporate management of investment process is an actual issue for international as well as for national scientific publications and papers. 
Theoretical and practical abilities of corporate management of investment process are discussed by the author in the article, also advantages and disadvantages associated with it.

\section{References:}

$\begin{array}{llllll}\text { Development } & \text { strategy } & \text { of } & \text { capital } & \text { market. } & \text { Tbilisi }\end{array} 2016$. http://www.economy.ge/uploads/meniu publikaciebi/ouer/kapitalis bazris ganvitarebis strategia. pdf;

Long-term economic development concept of Georgia. Business Association of Georgia. Tbilisi 2013. http://bag.ge/file.helix?i=499677ad-dbe6-49cf-ac6d-a08f1703f61c\&r=P;

Kbiladze,T.;Kbiladze D. (2016). TAX BURDEN INEQUALITY OF POPULATION IN GEORGIA AND CONCEPTUAL-METHODOLOGICAL PROBLEMS OF EVALUATION. 2016, Conference Proceedings, 24th International Academic Conference, Barcelona, DOI: 10.20472/IAC.2016.024.046, p.191-198

Social-economic development strategy of Georgia (project). Tbilisi. 2013 https://napr.gov.ge/source/\%E1\%83\%A1\%E1\%83\%A2\%E1\%83\%A0\%E1\%83\%90\%E1\%83\%A2 \%E1\%83\%94\%E1\%83\%92\%E1\%83\%98\%E1\%83\%90/ViewFile.pdf;

http://old.press.tsu.ge/GEO/internet/internetgak/STRATEGIULI/Tavi\%208.html

Кондратьев В.Б. Корпоративное управление и инвестиционный процесс. М., Наука, 2003;

Килячков А. Корпоративное управление как фрактор привлечения и защиты инвестиций//Рынок ценных бумаг. 2003;

Бочарова И. Ю. Корпоративное управление: учебник. - М.: ИНФРА-М, 2012; 